\title{
Elżbieta Rudnicka-Fira, Antroponimia Krakowa od XVI do XVIII wieku. \\ Proces kształtowania się nazwiska, Katowice 2004, ss. 608.
}

Wśród licznych w ostatnich latach publikacji opisujących nazewnictwo o określonym zasięgu terytorialnym i chronologicznym monografia Elżbiety Rudnickiej-Firy godna jest szczególnej uwagi i zainteresowania. Obszerne, składające się z sześciu rozdziałów części syntetycznej oraz słownika opracowanie w sposób wyczerpujący i wielowątkowy ukazuje proces kształtowania się nazwiska w jednym z najważniejszych ośrodków miejskich Polski trzech minionych wieków.

Aspekt demograficzny, socjologiczny, kulturowy okaże się niezwykle istotny w interpretacji materiału onomastycznego, czemu autorka daje wyraz w otwierającym Wstęp podrozdziale Obraz stosunków społeczno-gospodarczych $i$ narodowościowych w Krakowie od XVI do XVIII wieku (s. 9-17). Analizując zmieniającą się na przestrzeni trzech stuleci strukturę społeczną, zawodową, etniczną i demograficzną społeczności miasta, zwraca ona szczególną uwagę na tworzącą się (głównie w XVII i XVIII w.) grupę intelektualistów związaną z uniwersytetem. Jako ośrodek naukowy, ważny nie tylko w skali Polski, lecz i Europy, uniwersytet krakowski przyciągał obcych studentów, artystów, ludzi kultury i nauki, co z kolei zadecydowało o znacznym, ponad $20 \%$ udziale nazwisk obcych w antroponimii Krakowa.

Przy ustalaniu Zakresu i celu pracy (s. 17-19) autorka podkreśla, że „nadrzędnym celem monografii jest zgromadzenie w miarę obszernego i reprezentatywnego materiału antroponimicznego, jego możliwie wszechstronna analiza, zmierzająca do ukazania procesu kształtowania się (sposobów formowania i stabilizowania się) drugiego po imieniu członu nazwy osobowej, dziś powszechnie określanego nazwiskiem, w okresie od XVI do XVIII wieku" ( s. 17). Stara się przy tym "pokazać różne sposoby nazywania ludzi (modele identyfikacyjne), działające mechanizmy oraz różnorodność elementów identyfikacyjnych występujących w badanych dokumentach, prowadzące do utrwalania się przez wieki zwyczaju identyfikowania osób przez imię i nazwisko (w dzisiejszym rozumieniu)" (s. 18). Tak określonym zasadniczym celom rozprawy autorka podporządkowuje pewne szczegółowe zagadnienia badawcze, jak np. zależność między typem tekstu urzę- 
dowego a sposobem identyfikacji osób, stopień stabilizacji nazw osobowych z uwzględnieniem takich ich immanentnych cech, jak dziedziczność, rodzinność i stabilność, problem typologii (proto)nazwisk (męskich), ich aspekt formalny (typowe sufiksy nazwiskotwórcze), zjawisko wielomotywacyjności, sposoby i mechanizmy ich kreacji oraz kierunki procesów nazwiskotwórczych. Interesują ją ponadto relacje między nazwą określającą jednostkę a wspólnotą tworzącą aglomerację miejską, między typami nazwisk a statusem społecznym ich nosicieli. W sferze zainteresowań badaczki znajdują się zarówno nazwiska rodzime, jak i genetycznie obce.

Wyekscerpowany do analizy materiał antroponimiczny tworzy imponujący zbiór ponad 19 tysięcy zapisów ilustrujących różne sposoby identyfikowania ludzi głównie w źródłach rękopiśmiennych z lat 1500-1800, częściowo tylko w drukach z lat 1507-1611. Charakteryzując Wykorzystane źródła (s. 19-24), E. Rudnicka-Fira podkreśla, że najliczniejszą ich grupę stanowią księgi metrykalne (u rodzin, ślubów, zgonów), pochodzące z pięciu parafii krakowskich oraz księgi miejskie (sądowe, ławnicze, radzieckie, rachunkowe i in.), udostępniane w postaci mikrofilmów. Tę zasadniczą kolekcję źródeł uzupełniają wydane drukiem Księgi przyjęć do prawa miejskiego w Krakowie, zawierające wykazy nazw osób przyjmujących prawo miejskie. Uwzględniając założenia badawcze oraz ograniczenia wydawnicze ze zgromadzonego materiału źródłowego wyselekcjonowano jedynie „formy syntetyczne o odmianie rzeczownikowej lub przymiotnikowej (odnoszące się tylko do mężczyzn), które - jako drugie po imieniu - odpowiadają dzisiejszym nazwiskom" (s. 25). Nazwiska kobiet ze względu na odrębność formalnosemantyczną będą stanowiły przedmiot oddzielnej monografii; $w$ tej pracy przedstawiono jedynie ich schematyczną typologię.

Rozdział drugi rozprawy pt. Sposoby identyfikacji osób $w$ dokumentach krakowskich od XVI do XVIII wieku (s. 31-127) otwiera Wprowadzenie, w którym autorka dokonuje interesującego zabiegu porównania sposobów oznaczania osób $\mathrm{w}$ dwóch typach tekstów reprezentujących tę samą urzędową odmianę języka, lecz znacznie odległych od siebie czasowo. Zestawia zatem formuły XVI-, XVIIi XVIII-wieczne w księgach metrykalnych i miejskich z ich współczesnymi odpowiednikami, przytaczając adekwatne konteksty z ksiąg parafialnych, akt sądowych, notarialnych itp. Takie porównanie wskazuje na pewne podobieństwa w sposobach identyfikowania ludzi w analogicznych gatunkach tekstów, przede wszystkim jednak ujawnia różnice. W mocno sformalizowanych kontekstach współczesnych formuły odznaczają się dużym ujednoliceniem, schematyzmem, podczas gdy zapisy wcześniejsze, mimo cech pewnej szablonowości, wykazują znaczną dowolność i niejednolitość. W dużej mierze jest to konsekwencja nie ukończonego procesu desemantyzacji historycznych oznaczeń osobowych oraz ich predykatywnego (opisowego) charakteru. 
Klasyfikację identyfikacyjnych oznaczeń osobowych badaczka opiera na następujących kryteriach: płeć osoby identyfikowanej, liczba elementów identyfikujących, semantyczny charakter tych elementów. W ramach przyjętych kryteriów autorka analizuje odrębnie oznaczenia identyfikujące mężczyzn oraz kobiety. Ze względu na liczbę elementów identyfikujących zarówno w grupie oznaczeń męskich, jak i żeńskich wyróżnia modele jedno-, dwu-, trzy-, cztero-, pięcioi więcejskładnikowe, zaś wewnątrz wyszczególnionych typów formalnych materiał porządkuje według kryterium semantycznego, wyodrębniając oznaczenia wyrażone przez imię, nazwę odapelatywną, odmiejscową, patronimiczną, odetniczną, odzawodową, obcą i in., por. Sebastianus, Stanislaus de Olkusz, Nob. Joannes Kłosowicz, Thoma Dziubka de Łobzow, Mathia Zielionka szewc de Krowodrza, Joannes Josephus Ulbrycht Civis et Mercator Crac. etc. Pokazując bogactwo historycznych oznaczeń osobowych Rudnicka-Fira zwraca uwagę nie tylko na liczbę tworzących je elementów, ale też na ich szyk, wymienność oraz alternatywny charakter, wyróżnia np. oznaczenia z łacińskimi określeniami dictus, alias, cognominatus, vel, polskim rzeczony. Wiele cennych wniosków dotyczących procesu stabilizowania się nazw osobowych oraz ich funkcjonowania w kształtującej się odmianie języka urzędowego zawarła autorka w podsumowaniu rozdziału. Analizując zależność sposobów identyfikacji od czasu i stopnia standaryzacji tekstu prześledziła dokładnie proces przechodzenia od oznaczeń jednoczłonowych do wieloczłonowych, który ostatecznie prowadził do wykształcenia się modelu dwuczłonowego. Granice czasowe poszczególnych etapów wyznaczyć nie jest łatwo, gdyż $\mathrm{w}$ ich rozwoju nie było prostego przejścia od modelu jednoskładnikowego do dwuskładnikowego (imię + nazwisko), a na etapie przejściowym liczba elementów składowych określenia identyfikującego wahała się od jednego do kilku. Najbardziej znamienne dla procesu stabilizacji dzisiejszych nazwisk zmiany miały miejsce, jak wynika z ustaleń autorki, w XVII i XVIII w.

Rozdział trzeci monografii to szczegółowo przeprowadzona analiza Typów nazw osobowych (póziniejszych nazwisk) występujacych $w$ dokumentach krakowskich od XVI do XVIII wieku (s. 129-185). Skupiając się na typologii (proto)nazwisk męskich (schemat klasyfikacyjny nazwisk żeńskich zaprezentowano jedynie w celach porównawczych), E. Rudnicka-Fira za kryterium nadrzędne podziału przyjęła typ semantyczny podstawy, wyróżniając: (1) nazwiska pochodzące od innych kategorii nazw własnych, (2) nazwiska odapelatywne, (3) nazwiska genetycznie obce. W obrębie poszczególnych typów dokonała szczegółowej klasyfikacji formalno-semantycznej, co pozwoliło wyeksponować ogromne bogactwo i zróżnicowanie leksykalne antroponimii Krakowa: tkwiące w podstawach nazwisk imiona i ich derywaty (Jan, Chwalibóg, Pietrzyk), nazwy miejscowe (Zamojski, Kaliski, Wadowita), etnonimy (Węgrzyn, Słowaczek, Niemczyk), wyrazy pospolite, wśród których są formy regionalne lub przestarzałe (por. Momot, Kmieć, 
Gładysz), jak też nazwy zawodów, funkcji, godności (Fliśnik, Odźwierny, Sukien$n i k)$. Analizując poszczególne typy semantyczne (proto)nazwisk autorka wskazuje też na różne możliwości kreacji antroponimicznych. W grupie nazwisk odapelatywnych częstym zabiegiem jest przeniesienie w drodze derywacji semantycznej ze zmianą funkcji z płaszczyzny apelatywnej na płaszczyznę antroponimiczną, por. Miotła (< ap. miotła), Lipka (< ap. lipka), Dabrowa (< ap. dabrowa) i in. Przeniesienie ze zmianą pierwotnej funkcji - transonimizacja - może mieć miejsce również w obrębie nazw własnych, por. użycie w funkcji nazwisk nazw miejscowych Krosno, Mielec, Szczebrzeszyn lub nazw mieszkańców, np. Krakowczyk, Prażak, Wardanin. Odrębnym typem kreacji antroponimicznej jest derywacja słowotwórcza za pomocą formantów nazwiskotwórczych, np. -ski, -icz, -owicz/-ewicz, -czyk, -ek i in. Znaczącą rolę w kreacji nazwisk, zwłaszcza odapelatywnych (dawnych przezwisk), odegrały również metafory i metonimie.

Interesującą grupę w zasobie antroponimów Krakowa stanowią Nazwiska genetycznie obce (s. 166-185). Za takie badaczka uznała (za K. Rymutem) nazwy przetransponowane do polszczyzny jako gotowe jednostki leksykalne bez zmiany ich funkcji nazewniczej, nie posiadające motywacji na gruncie języka polskiego. Analiza nazwisk pochodzenia niemieckiego, poświadczonych największą liczbą zapisów (np. Schilling, Schedel, Waytman), włoskiego (Borgoni, Turini), francuskiego (Besson, Maxelan), wschodniosłowiańskiego (Czericzko, Zubek), litewskiego (Radziwitł, Troyden), węgierskiego (Bekesz, Rakocy), ormiańskiego (Awedyk), żydowskiego (Izraelowic), szkockiego (Forbes) $\mathrm{i}$ in. przeprowadzona została na tle bogatej panoramy kulturowej miasta, utrzymującego rozliczne kontakty polityczne, społeczne, kulturalne z całą ówczesną Europą. Większość z tych nazwisk, jak zauważa autorka, wykazuje cechy polonizacji, świadczące o różnym stopniu dostosowania się do norm rodzimej wymowy, ortografii, fleksji, czasem słowotwórstwa (por. Bayerowa, Szmidowic i in.), co może powodować określone trudności w rozpoznaniu antroponimu i właściwej jego interpretacji. Problemy takie pojawiają się zwłaszcza w odniesieniu do nazw pochodzących z języków wschodniosłowiańskich, pokrewnych polszczyźnie. Cytowana w monografii grupa takich nazwisk jest bardzo skromna, wydaje się jednak, że można ją poszerzyć przynajmniej o jeden antroponim. Chodzi o nazwę Burian (s. 173), chyba zbyt pochopnie, bo jedynie na podstawie końcówki -ian (o dodatkowej informacji kontekstowej wskazującej na etnos jej nosiciela badaczka nie wspomina) zakwalifikowaną do grupy odojcowskich nazwisk ormiańskich. Tymczasem, uwzględniając chociażby wielokrotnie sygnalizowane $\mathrm{w}$ pracy zjawisko wielomotywacyjności, formę tę można zapewne rozpatrywać jako ruską genetycznie formację odapelatywną, por. ap. brus., ukr. bur'jan, ros. burjan 'burzan' (M. Vasmer, Etimologičeskij slovar' russkogo jazyka, I, 249, Moskwa 1986). 
Rozdział czwarty Typy nazwisk a status społeczny ich nosicieli (s. 187-196) to znakomity szkic onomastyczno-socjologiczny społeczeństwa jednej z największych i najważniejszych aglomeracji miejskich Polski od XVI do XVIII w. Na podstawie danych liczbowych badaczka pokazała udział trzech najbardziej reprezentatywnych typów nazwisk (odmiejscowych, odapelatywnych i obcych) w różnych grupach społecznych i zawodowych ówczesnego Krakowa (tabela 1, s. 190). Analiza danych w kontekście zjawisk socjologicznych, demograficznych pozwoliła autorce zaobserwować pewną zależność typu nazwiska od proweniencji społecznej jego nosiciela: wyższa frekwencja nazwisk odmiejscowych wśród szlachty, odapelatywnych wśród mieszczan, zaś udział nazwisk obcych był większy w nominacji mieszczańskiej niż szlacheckiej. Ogólnie jednak fluktuacja poszczególnych typów nazwisk była duża, w efekcie czego występowały one w każdej grupie społecznej. „Zarówno chłop mógł mieć nazwisko odmiejscowe (na -ski) od wsi, z której pochodził, jak i szlachcic nazwisko odapelatywne typu przezwiskowego, mieszczanin zaś mógł nosić oba typy" (s. 193) - konkluduje E. Rudnicka-Fira. Spostrzeżenie to podważa zatem stereotypowe poglądy o możliwym rozdziale nazwisk na tzw. szlacheckie, mieszczańskie i chłopskie.

Aspekt kulturowy w interpretacji materiału antroponimicznego, ujawniający się z różnym natężeniem w poszczególnych partiach monografii, został wyeksponowany w krótkim rozdziale piątym Nazwiska mieszkańców Krakowa od XVI do XVIII wieku a kontekst historyczno-kulturowy (uwagi ogólne) (s. 197-202). Badaczkę interesuje to, „w jaki sposób na formę językową nazwisk, ich źródła leksykalne, zakres zastosowania rozmaitych typów nazwisk do identyfikacji różnych kategorii ludzi wpływały zjawiska zewnętrzne: $\mathrm{z}$ życia i ewolucji społeczeństwa, rozwoju miasta, kontakty międzyludzkie (także zagraniczne), zwyczaje i tradycje rodzinne oraz kształtujące się wzory obyczajowe” (s. 197). Ów specyficzny „kontekst historyczno-kulturowy" determinujący kształtowanie się nazewnictwa Krakowa wynikał z wyjątkowej pozycji miasta (przez długi czas) stołecznego, stanowiącego ważny ośrodek cywilizacyjny, kulturalny i naukowy Europy.

Część analityczną rozprawy zamykają Uwagi końcowe i wnioski (s. 203-209). Rozdział ten jest zwięzłą syntezą zaprezentowanych wcześniej szczegółowych analiz językowych.

Zgodnie z klasyczną dla monografii regionalnych dwudzielną kompozycją część analityczno-syntetyczną pracy uzupełnia obszerny słownik. Zaskakuje nieco układ owego antroponomastykonu. Być może ze względu na obszerność prezentowanego materiału źródłowego autorka ujmuje go w cztery grupy motywacyjne, powielając tym samym podział z części syntetycznej pracy. Niezależnie jednak od intencji badaczki układ taki nie ułatwia korzystania ze słownika. Aprioryczne bowiem założenie, że każdy czytelnik książki posiada podstawową wiedzę z zakresu motywacji nazwisk, która umożliwi mu bezbłędną lokalizację 
poszukiwanego antroponimu w jednej z czterech części słownika, jest chyba mało uzasadnione. A i wielomotywacyjność nazwisk, którą jako istotny problem metodologiczny badaczka kilkakrotnie podkreśla, za takim rozwiązaniem raczej nie przemawia. Wydaje się, że tradycyjny alfabetyczny układ haseł słownikowych, bez różnicowania antroponimów według typów semantycznych, byłby zdecydowanie bardziej czytelny.

Należy podkreślić, że te drobne uwagi krytyczne mają charakter wybitnie subiektywny, dotyczą bowiem kwestii tak wielce dyskusyjnych w metodologii badań, jak zasady redagowania onomastykonów, czy też trudnych do rozstrzygnięcia, a podnoszonych wielokrotnie przez E. Rudnicką-Firę, problemów wielomotywacyjności nazw lub wręcz hipotetyczności ich indywidualnych motywacji. Nie umniejszają one w niczym wartości merytorycznej pracy, dzięki której jej autorka jawi się czytelnikowi jako wnikliwa badaczka, dysponująca rozległą wiedzą językoznawczą, historyczno-kulturową, socjologiczną, stosująca nowe rozwiązania metodologiczne, obdarzona niezwykłą umiejętnością przechodzenia od drobiazgowych analiz trudnego materiału źródłowego do zwięzłych i trafnych syntez zaobserwowanych zjawisk językowych. 